\title{
MIR155 Pre-miRNA
}

National Cancer Institute

\section{Source}

National Cancer Institute. MIR155 Pre-miRNA. NCI Thesaurus. Code C82781.

MIR155 pre-miRNA is an oligoribonucleotide that is encoded by the human MIR155 gene and has a role in the regulation of gene expression. 